\title{
The benefit of compost on the growth of medicinal plant Brucea javanica (L.) Merr under drought stress
}

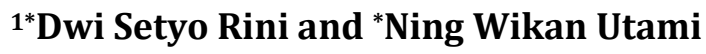 \\ Research Center for Biology, Indonesian Institute of Sciences (LIPI) \\ Cibinong Science Center (CSC), Jalan Raya Jakarta Bogor KM. 46 Cibinong 16911, Jawa Barat
}

Correspondence Author: Dwi Setyo Rini, Research Center for Biology, Indonesian Institute of Sciences (LIPI), Cibinong Science Center (CSC), Jalan Raya Jakarta Bogor KM. 46 Cibinong 16911, Jawa Barat

Email: dwi.setyo.rini@lipi.go.id

Received date: 28 August 2019, Accepted date: 15 November 2019, Online date: 26 November 2019

Copyright: (C) 2019 Dwi Setyo Rini and Ning Wikan Utami ., This is an open-access article distributed under the terms of the Creative Commons Attribution License, which permits unrestricted use, distribution, and reproduction in any medium, provided the original author and source are credited.

\begin{abstract}
Drought is known as the most destructive environmental cues affecting plant growth and productivity. Drought influences the decreasing soil water status, thereby disrupting nutrient uptake by the plant. As an organic fertilizer, compost has the ability to rectify the physical, chemical, and biological properties of the soil. This study was undertaken to find out the benefits of compost to reduce the negative impacts of drought stress on the growth of a medicinal plant, Brucea javanica (L.) Merr. Drought stress was performed to the growth medium by watering period treatments, i.e., watering every day (control), watering every 3 days, and watering every 7 days, whereas the compost treatments consist of two types of compost applications, i.e., soil medium without compost (control) and a mixture of soil medium with compost as the organic fertilizer at a ratio $2: 1(\mathrm{v}: \mathrm{v})$. The effects of compost were evaluated on the growth medium and the plant vegetative parameters at the harvesting time on 24-week B.javanica. Drought decreased both the water potential of the growth medium and RWC (relative water content) on the leaves of B.javanica. During drought, compost had the ability to suppress the lowering water potential of the growth medium and RWC on the plant leaves. Compost also improved the biomass production of the shoot of B.javanica plant subjected to the drought as compared to the plants without compost application. Therefore, compost can be used as an approach focusing on the growth medium to enhance plant productivity under drought.
\end{abstract}

Keywords: Brucea javanica (L.) Merr, compost, drought stress, plant growth.

\section{INTRODUCTION}

Brucea javanica (L.) Merr is an evergreen shrub plant which belongs to a member of the family Simaroubaceae. B.javanica species is widely distributed in tropical and sub-tropical areas in Southern China, Southeast Asia, New Guinea, and Northern Australia [1,2,3]. Well known as Ya-Tan-Zhu in China and buah Makasar in Indonesia [4], this plant could reach up to $3 \mathrm{~m}$ and grows up to $500 \mathrm{~m}$ above sea level. The fruit of this plant is oval, about $8 \mathrm{~mm}$ long, and being black if the fruit is ripe. The seed are round and have a white color and a bitter taste. B.javanica is well known as a medicinal plant due to its various chemical components, such as steroids [5], flavonoids [6,7], alkaloids [8], terpenoids [9], quassinoids [10,11], phenol [13], and lignans [14]. Therefore, parts of this plant can be used as medicines to reduce heat [15], cleanse toxins [16], stop bleeding (hemostasis) [17], and treat malaria [18]. It has been reported also that B.javanica has the activity as anti-inflammatory [1], antiviral [11], antihypertensive [17], antidiabetic [13,19], antitumor [20,21], and anticancer [22,23]. Brucea javanica also enhances immune function [24,25]. Drought stress is known as the most destructive abiotic stresses affecting plant growth and productivity [26]. Drought is defined as a period without significant rainfall. Generally, drought stress occurs when the available water in the soil decreases and atmospheric conditions cause continuous water loss due to the process of transpiration or evaporation. The severity of dry stress depends on many factors such as rainfall distribution, soil evaporation, and soil moisture storage capacity $[27,28]$. It has been reported that dry areas cover more than $40 \%$ of the world's land surface which the cultivated lands encompass $25 \%$ of total drylands area [29].

As sessile organisms, plants are constantly exposed to a plethora of environmental cues throughout their life. As a consequence, they have evolved a set of strategies that allow them to cope with water deficit conditions [30]. In addition to the severity and duration of stress, plant response to drought also depends on the growth stage of the plant. It is considered that cell growth is one of the most drought-sensitive physiological responses of plants [31,32]. As a result of the complex interaction between cell division, cell enlargement, and cell differentiation, plant growth inhibition can arise due to lacking water availability for the growing cell $[33,34]$. Impairing in the processes of cell mitosis, elongation, and expansion, lead to the reduction in plant height, 
leaf area, root growth, and biomass production under drought. Reduced plant growth under water stress was observed in several crop plants, such as rice [35,36], wheat [37,38], millet [39], corn [40], pea [41,42], potato [43], and soybean [44].

Fertilizer is the material given to plants that function to change the physical, chemical or biological properties of the soil and to complement nutrient availability for better plant growth. Chemical/ inorganic fertilizer is a fertilizer type from chemical substances as plant nutrients. However, continuous use of inorganic fertilizers on a large scale will cause environmental degradation problems. In overcoming this problem, the utilization of organic and biological fertilizer is the right choice related to the development of sustainable agriculture mechanisms. As one of organic fertilizers, compost plays a very significant role in improving soil fertility and soil properties, thereby promoting plant growth and productivity. As a mixture of many organic wastes, compost application can be used as a source of organic matter (SOM) to provide macro and micro-nutrients for the plant, such as phosphorus and nitrogen [45,46], as well as to build organic carbon stocks in the soil [47]. Furthermore, compost functions to enhance soil aggregation and stability. These factors are required for improving soil structure and porosity which are very important not only for root proliferation in plants but also for gas exchange, water movement and microbial activity for soil fertility $[48,49]$.

This study was performed to evaluate the effects of compost on the growth of B.javanica under drought stress. Due to a high level of its exploitation as a medicinal plant, it is necessary to conduct research related to the aspect of sustainable cultivation of this plant under drought stress conditions. The effect of compost as organic fertilizers on soil water content and plant growth under water deficit conditions is just little known [50]. Therefore, the results of this study are expected to provide information about the function of compost in improving the growth of B.javanica plants cultivated on drylands.

\section{MATERIALS AND METHODS}

\section{Experimental design}

The experiment in this study was arranged in a completely randomized design with two-factor treatments, namely drought stress and compost, with four replications. The drought stress treatment was comprised of three levels of watering periods, which the treatments are P1 = watering every day as a control treatment, P2 = watering every three days, and P3 = watering every seven days. Plant watering was performed until it reached $100 \%$ field capacity as determined by the weight of the growth medium. The compost treatments consist of two types of compost application on the growth medium, namely M1 = $100 \%$ soil without compost, and $\mathrm{M} 2=$ a mixture of soil and compost as an organic fertilizer at a ratio 2: $1(\mathrm{v} / \mathrm{v})$. The physicochemical characters of compost used in this study are presented in Table 1.

Seeds of B.javanica used for this experiment are germplasm collection of Plant Physiology Laboratory, Division of Botany, Research Centre for Biology, Indonesian Institute of Sciences (LIPI). The seeds were germinated in petri dishes containing moistened absorbent paper in a germination chamber for 2 weeks. The uniformly germinated seeds then were transferred in the pot-based system $(\varnothing=28 \mathrm{~cm}$, height: $35 \mathrm{~cm}$, filled with $8 \mathrm{~kg}$ growth medium) and acclimatized in the greenhouse with temperature $300 \mathrm{C} \pm 50 \mathrm{C}$, relative humidity $60 \% \pm 20 \%$, and a natural photoperiod. Compost and drought stress treatments started to be subjected to the growth medium when the plants already reached 4-week old. The observation was performed at the harvesting time on 24-week old plants.

Table 1. Physico-chemical characters of compost used in this study

\begin{tabular}{|l|ll|}
\multicolumn{1}{|c|}{ Characters } & \multicolumn{2}{c|}{ Value } \\
\hline Cation Exchange Capacity (CEC) & $13.56 \quad \mathrm{cmol} / 100 \mathrm{~g}$ \\
\hline C - Organic & $5.33 \quad \%$ \\
\hline Total K & 0.36 & $\mathrm{cmol} / 100 \mathrm{~g}$ \\
\hline Total N & $0.21 \quad \%$ \\
\hline $\mathbf{C} / \mathbf{N}$ & 25.38 & \\
\hline $\mathbf{N a}$ & 8.39 & $\mathrm{ppm}$ \\
\hline $\mathbf{P}$ & 342.02 & $\mathrm{ppm}$ \\
\hline $\mathbf{M n}$ & 458.28 & $\mathrm{ppm}$ \\
\hline $\mathbf{C u}$ & 22.86 & $\mathrm{ppm}$ \\
\hline $\mathbf{F e}$ & 22.75 & $\mathrm{ppm}$ \\
\hline $\mathbf{Z n}$ & 45.05 & $\mathrm{ppm}$ \\
\hline
\end{tabular}

\section{Water potential status and temperature of the growth medium}

The water potential (PA) on growth medium in every treatment was analyzed by using Dewpoint Potentia Meter WP4. This measurement was performed at harvesting time on 24-week plants. About $10 \mathrm{~g}$ of growth medium were used to quantify its water potential value. Furthermore, the WP4 instrument was also used to measure the temperature of the growth medium.

\section{Relative Water Content (RWC)}

In order to determine relative water content (RWC) in leaves, the fresh 4-cm diameter of fully expanded leaves of B.javanica plant was sampled, weighed (FW), and then placed in distilled water in Petri dishes for 48 hours in the dark conditions for full turgidity. Afterwards, the turgidity of leaves (TW) was measured. The dry weight of leaves was recorded after the leaves were dried in an oven with a temperature of $600 \mathrm{C}$ for 48 hours until leaves attained the constant weight. Relative water content in leaves was calculated according to the following method given by Mayak et al [51]: 


$$
\mathrm{RWC}=\frac{\mathrm{FW}-\mathrm{DW}}{\mathrm{TW}-\mathrm{DW}} \times 100 \%
$$

$\mathrm{FW}=$ fresh weight of leaves, DW = dry weight of leaves, $\mathrm{TW}=$ turgid weight of leaves. RWC of leaves was calculated by using 5 leaves in every treatment.

\section{Vegetative growth parameters}

Several vegetative growth parameters measured in this study were the leaf number, stem diameters, shoot length, root length, fresh weight and dry weight of the shoots, as well as fresh weight and dry weight of the roots. The leaf number was counted on all fully expanded leaves in the plant. The height of the plant was measured from the base of the plant up to the tip of the shoot. The length of the root was measured on the primary root, from the base of the root that borders to the base of the plant to the tip of the root. For the biomass parameter, the fresh weight of shoots and roots were recorded on fresh weight shoots and roots at harvesting time. The dry weight of shoots and roots was analyzed on shoots and roots after being dried in an oven at $600 \mathrm{C}$ for 3 days until it reached a constant weight.

\section{Statistical analysis}

Analysis of variance was performed on water potential and temperature of the growth medium, relative water content (RWC), and vegetative growth parameters according to a factorial design. Each treatment and their correlation were statistically analyzed by using SigmaStat software. LSD (Least Significant Different) test at a 5\% level was used to determine significant differences in the measured parameters.

\section{RESULTS}

\section{Water potential status and temperature of growth medium}

The watering period treatments generated a negative effect on the water potential of the growth medium (Fig. 1B). In this study, the lowest water potential in the growth medium which reached $-9.77 \mathrm{MPa}$, was obtained on M1P3 treatment. P3 treatment performed drought stress level which was more than that P1 and P2 treatments. It means that an increase in the duration of the watering period treatments leads to a decrease in the water potential of the growth medium. However, the application of compost (M2) had the ability to suppress the decreasing water potential of the growth medium under drought stress. Though compost treatment showed its effect on the growth medium under water deficit conditions, it had no effect on the temperature of the growth medium (Fig.1B).

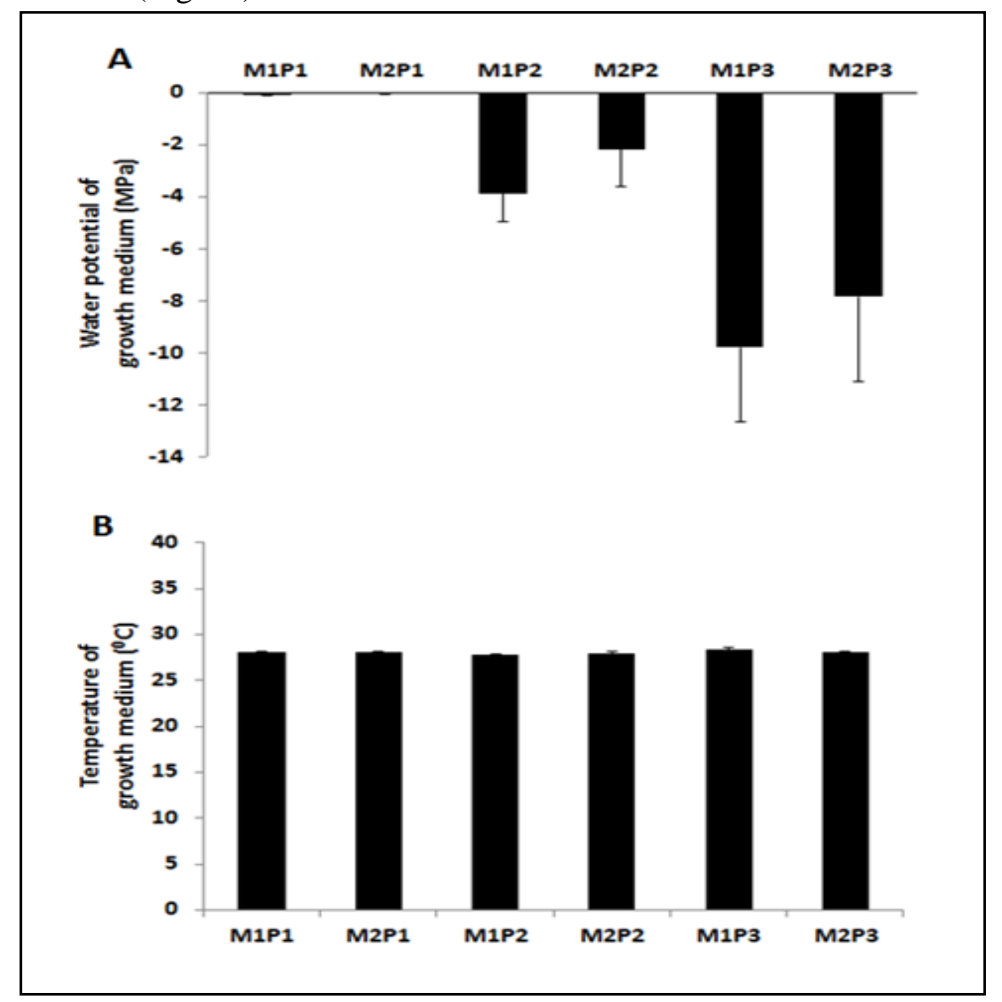

Figure 1. Water potential and temperature of the growth medium. The measurement was performed at harvesting time on 24-week plants. M1P1 = Soil $(100 \%)$ without compost in the treatment of watering every day, M2P1 = Soil with compost $(2: 1, \mathrm{v} / \mathrm{v})$ in the treatment of watering every day, M1P2 = Soil without compost in the treatment of watering every three days, M2P2 = Soil with compost $(2: 1$, v/v) in the treatment of watering every three days, M1P3 = Soil without compost in the treatment of watering every seven days, and M2P3 = Soil with compost $(2: 1, v / v)$ in the treatment of watering every seven days. Data are means $\pm \operatorname{SD}(n=4)$. 
Water deficit performed by watering period treatment exerted a negative effect on RWC of B.javanica leaves. As shown in Figure 2, the presence of compost in the growth medium subjected to drought stress induced the RWC on the leaves of B.javanica (M2P3). The leaves of B.javanica lost much more water in $\mathrm{P} 3$ treatment as compared to those in $\mathrm{P} 1$ and $\mathrm{P} 2$ treatments.

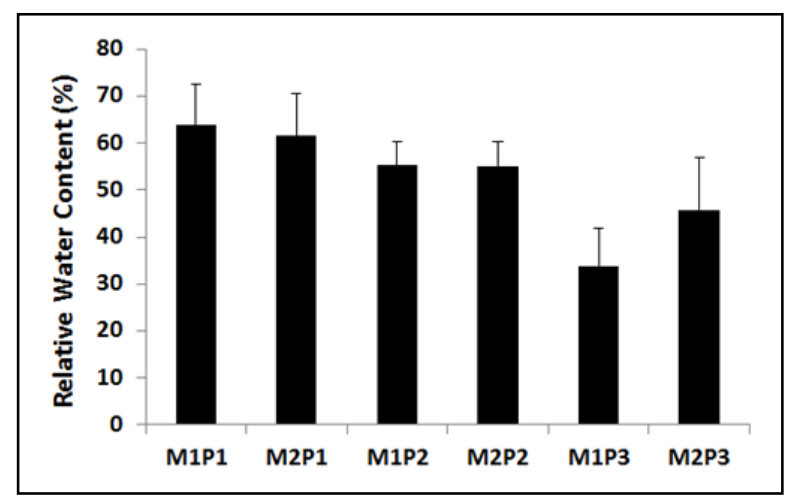

Figure 2. Relative Water Content $(\mathrm{RWC})$ of B.javanica leaves. The data was collected at the harvesting time on 24 -week plants. M1P1 = Soil $(100 \%)$ without compost in the treatment of watering every day, M2P1 = Soil with compost $(2: 1, \mathrm{v} / \mathrm{v})$ in the treatment of watering every day, M1P2 = Soil without compost in the treatment of watering every three days, M2P2 = Soil with compost $(2: 1$, v/v) in the treatment of watering every three days, M1P3 = Soil without compost in the treatment of watering every seven days, and M2P3 = Soil with compost $(2: 1$, $\mathrm{v} / \mathrm{v})$ in the treatment of watering every seven days. Data are means $\pm \operatorname{SD}(n=4)$.

\section{Vegetative Growth}

Compost applied to the growth medium showed a positive effect as compared to medium without compost in the parameter of relative leaf number (Fig. 3A). Well-watered plants had the ability to maintain their leaves number in the presence of compost in the growth medium, whereas plants grown in the medium without compost lost many of their leaves. Even though decreased leaves number was presented in the plants grown in the medium with the treatments of watering every three days and every seven days, but it was less in the presence of compost in the growth medium. The highest relative leaf number in 24 -week plants was reached by the watering everyday treatment with the application of the compost in the growth medium. However, the highest rate $(\sim 90 \%)$ of decreasing leaf number was performed in B.javanica plants grown in the medium without compost and with a watering period every seven days (M1P3). Compost application presented similar result with the treatment without compost in the growth medium in all of watering period treatments in the parameter of relative plant height (Fig. 3B). Compost application presented a similar effect as compared to the medium without compost in 24-week plants in relative steam diameter (Fig. 3C).

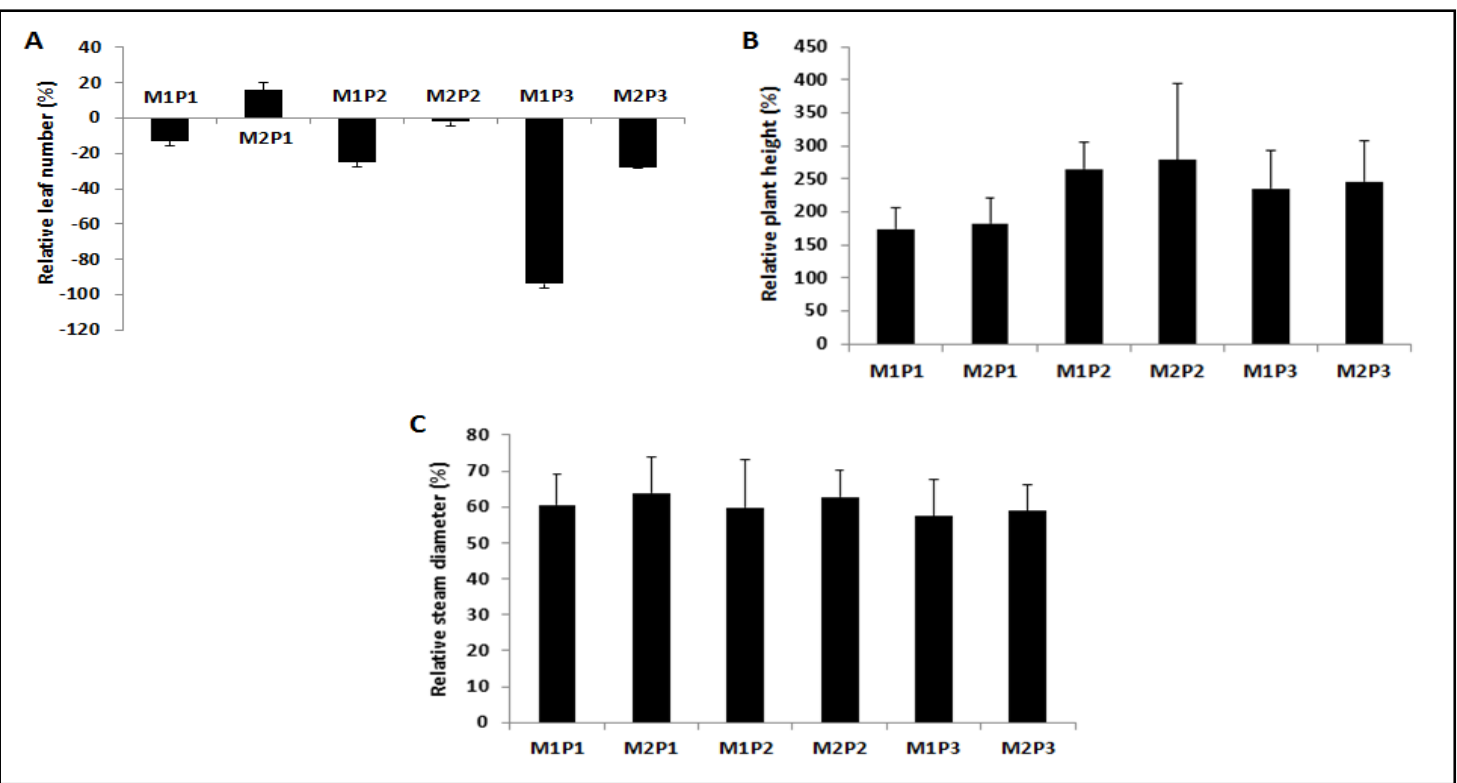

Figure

Vegetative growth measurement of B.javanica. A. Relative leaf number, B. Relative plant height, C. Relative steam diameter. Vegetative growth measurement was performed on 24-week plants and then compared to the measurement on 8-week plants to determine its relative. M1P1 = Soil $(100 \%)$ without compost in the treatment of watering every day, M2P1 = Soil with compost $(2: 1$, v/v) in the treatment of watering every day, M1P2 = Soil without compost in the treatment of watering every three days, M2P2 = Soil with compost $(2: 1$, v/v) in the treatment of watering every three days, M1P3 = Soil without compost in the treatment of watering every seven days, and M2P3 = Soil with compost $(2: 1, v / v)$ in the treatment of watering every seven days. Data are means $\pm \operatorname{SD}(n=4)$.

Biomass production under drought is an important trait for crop production. Drought performs a negative impact on biomass accumulation during the plant growth stage. Compost significantly induced the shoot and root biomass of B.javanica plant as compared to the medium without compost under the normal conditions (Table 2). The fresh and dry weight of the shoot by the application of compost was significantly different from those in the growth medium without compost under drought stress 
generated by a watering period every three days. Compost also increased significantly the fresh weight of shoot under the treatment of every seven days watering periods. Meanwhile, the application of compost at the ratio of soil: compost (2: 1, v/v) was not significantly different in the fresh and dry weight of root under drought stress conditions.

Table 2. Interaction of drought stress and compost applications on the biomass of B.javanica plants

\begin{tabular}{lllllll}
\hline $\begin{array}{l}\text { Drought } \\
\text { treatments }\end{array}$ & stress & Compost treatments & $\begin{array}{l}\text { Shoot fresh } \\
\text { weight (g) }\end{array}$ & $\begin{array}{l}\text { Shoot dry } \\
\text { weight (g) }\end{array}$ & $\begin{array}{l}\text { Root fresh } \\
\text { weight (g) }\end{array}$ & $\begin{array}{l}\text { Root } \\
\text { weight (g) }\end{array}$ \\
\hline Watering & every & Non compost (Control) & $39.03^{\mathrm{a}}$ & $11.88^{\mathrm{a}}$ & $16.50^{\mathrm{a}}$ & $7.13^{\mathrm{a}}$ \\
day & & $68.80^{\mathrm{b}}$ & $21.20^{\mathrm{b}}$ & $27.00^{\mathrm{b}}$ & $13.23^{\mathrm{b}}$ \\
\hline Watering & every & Non compost (Control) & $34.43^{\mathrm{a}}$ & $10.40^{\mathrm{a}}$ & $14.80^{\mathrm{a}}$ & $4.38^{\mathrm{a}}$ \\
three days & & Compost & $61.95^{\mathrm{b}}$ & $17.88^{\mathrm{b}}$ & $16.88^{\mathrm{a}}$ & $5.00^{\mathrm{a}}$ \\
\hline \multirow{2}{*}{$\begin{array}{l}\text { Watering } \\
\text { seven days }\end{array}$} & \multirow{2}{*}{$\begin{array}{l}\text { every } \\
\text { Non compost (Control) }\end{array}$} & $15.98^{\mathrm{a}}$ & $6.90^{\mathrm{a}}$ & $5.70^{\mathrm{a}}$ & $1.93^{\mathrm{a}}$ \\
& & Compost & $23.80^{\mathrm{b}}$ & $8.05^{\mathrm{a}}$ & $6.57^{\mathrm{a}}$ & $2.43^{\mathrm{a}}$ \\
\hline
\end{tabular}

Values are the averages for each group $(n=4)$. For each column, different letters indicate significant differences by $t$-test $(p<$ 0.05 ) at the same drought stress treatment. The measurement was performed in the harvesting time on 24-week plants.

\section{DISCUSSIONS}

Drought is considered as one of the most environment constraints all over the world. Drought leads to a strong impact due to disrupting the water status both of the soil and the plant tissue, thereby affecting plant growth and productivity. A decrease in water potential is considered as one of the quantitative parameters that can be used to indicate the level of dryness of the soil [52]. In this study, drought-affected the decrease in the water potential of B.javanica growth medium. As shown in Figure $1 \mathrm{~A}$, the value of soil water potential was formed in a more negative level by increasing the duration of water period treatments. According to this result, it can be underlined that the higher level of soil water deficit resulted in the more negative of the soil water potential value. In corresponding with this study, research conducted by Lee and Mudge [53] on water soil status in the growth medium of American ginseng (Panax quinquefolius L.) also showed that the water potential of the growth medium presents a decreased value by progressing its water deficit. These conditions are in accordance with what was stated by Jones [54] that the lowering soil water potential is a consequence of a system subjected to water shortage.

Various approaches have been developed to enhance plant productivity under drought. The use of drought-tolerant cultivars to improve plant yield is a considerable part of approaches in this matter. However, another approach must be taken in the growth medium site to overcome drought experienced to the plants. During water deficit, a strategy is required to reduce the evaporation from the soil so that its humidity cannot decrease dramatically. Compost can decrease soil evaporation in the growth medium [55]. It is due to the responsibility of compost to enhance water-holding capacity thereby increasing soil water availability [56]. The amount of water that is accessible to a growing plant will depend on two elements: the quantity of water that is capable to penetrate into the soil and the quantity of water that the soil is able to maintain onto [57]. Compost administrated in the growth medium is seen as an approach that can be used to reduce the negative impact of drought on the plants. In this study, compost, however, functioned to suppress the decreasing of soil water potential in the medium under water stress conditions (Fig. 1A). It means that compost in the growth medium performed the soil water potential which was less negative as compared to the growth medium without compost. Under drought stress, compost allowed the soil to hold more water which then was needed by the plant for growth and development processes. This has corresponded to the result of relative water content (RWC) on the leaves of B.javanica plants. The ability of compost to suppress the negative level of soil water potential in the growth medium resulted in the increasing level of relative water content (RWC) of the plant by compost under P3 treatment (Fig. 2). It has been reported that relative water content (RWC) in the plant leaves is an essential barometer of water status in plants which expresses the balance between water supply to the leaf tissue and transpiration rate [58]. Drought decreases leaf relative water content (RWC) on the plant species [59]. Plants having more resistant characters toward drought show a higher RWC as compared to the sensitive ones.

During drought conditions which lead to decreasing of soil water potential (Fig. 1A), the ability of the plant to uptake nutrients from the soil is also decreased [60]. This is due to the reduction in nutrients diffusion rate from the soil to the absorbing root surface [61]. Moreover, several conditions, such as reduced transpiration, impaired active transport and membrane permeability under drought also affect the reduction of plant ability in the nutrient uptake process. Taken together, these conditions during drought caused negative impacts on the vegetative growth of B.javanica plant (Fig. 3). Compost applied to the soil had the ability to minimize the reduction of B.javanica growth under drought. As one of the organic fertilizers, compost replenishes particularly soil organic matter and provides nutrients for the plant [62]. The organic matter, and also macro and micronutrients of compost used in this study, such as $\mathrm{C}$-organic, $\mathrm{N}, \mathrm{P}, \mathrm{K}, \mathrm{Na}, \mathrm{Mn}, \mathrm{Cu}, \mathrm{Fe}$, and $\mathrm{Zn}$ (Table 1) serves as a vital component in soil fertility by improving soil aggregation, structure stability, and water infiltration [63]. Furthermore, compost also can improve the physical, chemical, and biological properties of soils [64].

As described in Table 2, compost can stimulate plant growth in several parameters, such as fresh weight and dry weight of the shoots of B.javanica plants. Compost used in this study contributed to the addition of $5.33 \%$ C-organic in the growth medium. Besides as an energy source for microorganisms activity, C-organic also has the functions to increases the capacity of the soil to maintain nutrients and the soil cation exchange [65]. Compost containing essential macronutrients, such as nitrogen $(\mathrm{N})$, phosphorus $(\mathrm{P})$, and potassium $(\mathrm{K})$ (Table 1), were supplied to the growth medium to increase their concentration as plant 
nutrition for growth and development. In addition, micronutrients provided by compost, such as $\mathrm{Mn}, \mathrm{Na}, \mathrm{Cu}, \mathrm{Fe}$, and $\mathrm{Zn}$ (Table 1) are always required in very little amounts but play a very important role in the physiological processes of the crop plants. However, the humic substances in compost also contribute to the enhancement of the shoot biomass production via the hormonal effect on root elongation and plant development [66]. When the plant loses its turgor during dry conditions, compost will increase the transpiration process to prevent overheating on the leaf surface. Due to its high-water use, increasing of transpiration process can stimulate biomass production of the shoots and leaf area index [53].

\section{CONCLUSION}

As an approach to enhance plant productivity under drought, compost applications have performed several points to improve the soil characters and plant growth. Compost adds the organic matter to promote the process of water interacting with the soil. Compos suppressed the decreasing water potential of the growth medium and relative water content (RWC) on the plant leaves. Compost also improved the biomass production of the plant shoot subjected by drought as compared to the growth medium without compost due to the macro and micronutrients consisted in the compost.

\section{ACKNOWLEDGEMENTS}

The authors thank the Research Centre for Biology, Indonesian Institute of Sciences (LIPI) for supporting this research. We also thank the reviewers and editor for evaluation that helped to improve the manuscript.

\section{REFERENCES}

[1] Li, Q., L.Yang, L. Fan, C. Liang, Q. Wang, H. Wen, J. Dai, X. Li, Y. Zhang, 2018. Activity of Brucea javanica oil emulsion against gastric ulcers in rodents. Asian Journal of Pharmaceutical Sciences, 13(3):279-288.

[2] Sun, Z., Cao, Yang; Zhai, Lin-zhu. 2017. Java brucea and Chinese herbal medicine for the treatment of cholesterol granuloma in the suprasellar and sellar regions: A case report and literature review. Medicine, 96(5).

[3] Zhao L., C.Li, Y. Zhang, Q. Wen, D. Ren, 2014. Phytochemical and biological activities of an anticancer plant medicine: Brucea javanica. Anticancer Agents Med Chem., 14:440-58.

[4] Voeks, R.A., 2018. The ethnobotany of eden: Rethinking the jungle medicine narrative. U Chicago Press, 328 pp.

[5] Widiyantoro, A., E.R.P. Wardoyo, E. Sayekti, 2010. Activity of makasar fruit (Brucea javanica L Merr) on radical anion superoxide in vivo. Saintek Journal, 15(1). https://doi.org/10.21831/jps.v15i1.

[6] Fei, A., J. Jiang, Y. Wang, Z. Fang, Y. Teng, X. Hao, 2018. Response surface optimization of ultrasonic assisted extraction of flavonoids from Brucea javanica. MATEC Web of Conferences 238, 04005.

[7] Ismail, N., H. Abdullah, S. Jamil, S.M.S.S. Jamalullai, D. Rotondo and V. Seidel, $2012 . \quad$ Anticancer and immunomodulating activity of a flavonoid from Brucea javanica leaves, UMT $11^{\text {th }}$ International Annual Symposium on Sustainability Science and Management, $09^{\text {th }}-11^{\text {th }}$ July 2012, Trengganu, Malaysia.

[8] Samat, N., M. Ng, H. Lee, S. Ling, et al., 2017. Canthin-6-one isolated from Brucea javanica root blocks cancer cells in the G2/M phase and synergizes with cisplatin. Natural Product Communications. 12. 771-778.

[9] Dong, S.H., J. Liu, Y.Z. Ge, L. Dong, C.H. Xu, J. Ding, J.M. Yue, 2013. Chemical constituents from Brucea javanica, Phytochemistry, 85 (2013): 175-184.

[10] Chumkaew, P., P. Atiphon, W. Uraiwan, S. Theera, 2019. A New quassinoid from Brucea javanica and its antiplasmodial and cytotoxic activities. Chemistry of natural compounds, 55(3).

[11] Lahrita, L., K. Moriai, R. Iwata, K. Itoh, E Kato. 2019. Quassinoids in Brucea javanica are potent stimulators of lipolysis in adipocytes. Fitoterapia. 2019 Sep;137:104250. doi: 10.1016/j.fitote.2019.104250. Epub 2019 Jul 2. PubMed PMID: 31271784.

[12] Ryu, S.M., J. Kwon, Y.H. Seo, E.G. Song, S.S. Hong, B.S. Kim, J.S. Hong, K.H. Ryu, D. Lee, 2017. Quassinoids isolated from Brucea javanica inhibit pepper mottle virus in pepper. Virus Res, 2(227):49-56. doi: 10.1016/j.virusres.2016.09.013. Epub 2016 Sep 26. PubMed PMID: 27686478.

[13] Ablat, A., M.F. Halabi, J. Mohamad, et al., 2017. Antidiabetic effects of Brucea javanica seeds in type 2 diabetic rats. BMC Complement Altern Med., 17(94). doi:10.1186/s12906-017-1610-x

[14] Yang, J., W. Liu, S. Li, H.Ye, H. Tang, L. Chen and A. Peng, 2014. Coumarinolignans isolated from the seeds of Brucea javanica. HCA, 97: 278-282. doi:10.1002/hlca.201300127

[15] Jin, W., H. Han, S. Zhou, Y. Wang, T. Dong, C. Zhao, 2015. Therapeutic efficacy of Brucea javanica oil emulsion (BJOE) combined with transcatheter hepatic arterial chemoembolization (TACE) in patients with primary liver cancer. Int J Clin Exp Med, 8(10):18954-18962.

[16] Helmi, H and I. Susanti, 2015. Phytochemical tested and in vitro screening antimalaria activity of Belilik Brucea javanica L Merr against Plasmodium falcifarum. Journal of Biological Researches, 19. 1-4. 10.23869/bphjbr.19.1.20133.

[17] Roswiem, A.P., B. Kiranadi, T.S.P. Bachtiar and R. Ranasasmita, 2012. Antihypertensive effect of Brucea javanica (L.) Merr. fruit extract. Makara Journal of Science, 16(2):71-76.

[18] Kefe, A., M. Giday, H. Mamo, et al, 2016. Antimalarial properties of crude extracts of seeds of Brucea antidysenterica and leaves of Ocimum lamiifolium BMC Complement Altern Med., 16(118) doi:10.1186/s12906-016-1098-9

[19] Simamora, A., T.K. Herawan and S.A. Widodo, 2019. Antidiabetic, antibacterial and antioxidant activities of different extracts from Brucea javanica (L.) Merr seeds. Pharmacognosy Journal, 11(3):479-485.

[20] Shi, W-R., Y, Liu., X-T, Wang., Q-Y, Huang., X-R, Cai., S-R, Wu., 2015. Antitumor efficacy and mechanism in hepatoma H22-bearing mice of Brucea javanica oil. Evidence-Based Complementary and Alternative Medicine, 2015 : 1-8. 
[21] Mu, L-Q., W, Dai, C-B, Wang., X-Y, Liu., D-X, Xiang., T-T, Liu., 2016. Preparation, characterization, and evaluation of antitumor effect of Brucea javanica oil cationic nanoemulsions. International Journal of Nanomedicine, (11):2515-2529.

[22] Yan, Z., G.F. Guo, B, Zhang., 2017. Research of Brucea javanica against cancer. Chin J. Integr. Med., 23(3): 153-160.

[23] Wu, J-R., S-Y, Liu., J-L, Zhu., D, Zhang., K-H, Wang., 2018. Efficacy of Brucea javanica oil emulsion injection combined with the chemotherapy for treating gastric cancer: A systematic review and meta-analysis. Evidence-based complementary and alternative medicine, $2018: 1-10$.

[24] Xu, W., X. Jiang, Z. Xu, T. Ye, Q. Shi, 2016. The efficacy of Brucea javanica oil emulsion injection as adjunctive therapy for advanced non-small-cell lung cancer: A meta-analysis. Evid Based Complement Alternat Med., $2016: 5928562$. doi:10.1155/2016/5928562.

[25] Yu, Z., Y. Like, X. Ning, 2014. Effect of Brucea Javanica oil emulsion combined with GP regimen on the immune function of patients with advanced non-small cell lung cancer. Journal of International Translational Medicine, 2(1): 262-265.

[26] Khan, A., X. Pan, U. Najeeb, et al., 2018. Coping with drought: stress and adaptive mechanisms, and management through cultural and molecular alternatives in cotton as vital constituents for plant stress resilience and fitness. Biol Res., 51(1):47. doi:10.1186/s40659-018-0198-z.

[27] Berg, A and J. Sheffield, 2018. Climate change and drought: The soil moisture perspective. Curr Clim Change Rep., 4(2): 180-191, https://doi.org/10.1007/s40641-018-0095-0.

[28] Boulet, G., E. Delogu, S.Saadi, W. Chebbi, et al., 2018. Evapotranspiration and evaporation/transpiration partitioning with dual source energy balance models in agricultural lands. Proc. IAHS, 380:17-22.

[29] FAO. 2008. Water and cereals in drylands. Drylands, people, and land use. Rome, Italy.

[30] Bouzid, M., F. He, G. Schmitz, et al., 2019. Arabidopsis species deploy distinct strategies to cope with drought stress. Ann Bot., 124(1):27-40. doi:10.1093/aob/mcy237

[31] Shan, Z., X. Luo, M. Wei, et al., 2018. Physiological and proteomic analysis on long-term drought resistance of cassava (Manihot esculenta Crantz). Sci Rep 8, (7982) doi:10.1038/s41598-018-35711-X

[32] Avramova, V., H. AbdElgawad, Z.Zhang, et al.,2015. Drought induces distinct growth response, protection, and recovery mechanisms in the maize leaf growth zone. Plant Physiol., 169(2):1382-1396. doi:10.1104/pp.15.00276.

[33] Wu, L-M., Y. Fang, H-N. Yang, L-Y. Bai, 2019. Effects of drought-stress on seed germination and growth physiology of quinclorac-resistant Echinochloa crusgalli. PLoS ONE 14(4): e0214480. https://doi.org/10.1371/journal.pone.0214480.

[34] Farquharson, K.L, 2017. Fine-tuning plant growth in the face of drought. The Plant Cell, 29(1).

[35] Yang, X., B. Wang, L. Chen, et al., 2019. The different influences of drought stress at the flowering stage on rice physiological traits, grain yield, and quality. Sci Rep., 9(3742) doi:10.1038/s41598-019-40161-0.

[36] Dien, D.C., M. Toshihiro, T. Yamakawa, 2019, Effect of various drought stresses and subsequent recovery on proline, total soluble sugar and starch metabolisms in rice (Oryza sativa L.) varieties. Plant Production Science, 22(4): 530-545, DOI: 10.1080/1343943X.2019.1647787.

[37] Sallam, A., A.M. Alqudah, M.F.A. Dawood, P.S. Baenziger, A. Börner, 2019. Drought stress tolerance in wheat and barley: Advances in physiology, breeding and genetics research. Int J Mol Sci., 20(13):3137. doi:10.3390/ijms20133137.

[38] Yadav, A.K., J. C. Adam, G.M. Estavillo, G. J. Rebetzke, B.J. Pogson, 2019. Wheat drought tolerance in the field is predicted by amino acid responses to glasshouse-imposed drought. Journal of Experimental Botany, 70(18):4931-4948, https://doi.org/10.1093/jxb/erz224.

[39] Nematpour, A., H.R. Eshghizadeh, M. Zahedi, 2019. Drought-tolerance mechanisms in foxtail millet (Setaria italica) and proso millet (Panicum miliaceum) under different nitrogen supply and sowing dates. Crop and Pasture Science, 70(5): 442452, https://doi.org/10.1071/CP18501

[40] Wang, B., Liu, C., Zhang, D. et al. Effects of maize organ-specific drought stress response on yields from transcriptome analysis. BMC Plant Biol 19, 335 (2019) doi:10.1186/s12870-019-1941-5.

[41] Vernoud, V., N. Rossin, M. Prudent, C. Le Signor, M. Sanchez, et al., 2016. A transcriptomic approach identifies candidate genes for drought tolerance during the reproductive phase in pea. International Legume Society Conference - Legumes for a Sustainable World, Lisbonne, Portugal. 358 p. 〈hal-01604112〉.

[42] Osman, H.S., 2015. Enhancing antioxidant-yield relationship of pea plant under drought at different growth stages by exogenously applied glycine betaine and proline. Annals of Agricultural Science, 60(2):389-402.

[43] Obidiegwu, J., B. Glenn, J. Hamlyn, P. Ankush, 2015. Coping with drought: stress and adaptive responses in potato and perspectives for improvement. Frontiers in Plant Science, 6: 542.

[44] Nasir, I., H. Sajad, R.M. Ali, Y. Cai-Qiong, S.M. Ehsan, B. Marian, A. Ahsan, et al., 2019. Drought tolerance of soybean (Glycine max L. Merr.) by improved photosynthetic characteristics and an efficient antioxidant enzyme activities under a split-root system, Frontiers in Physiology, 10: 786

[45] Verma, S., A, Sharma., R, Kumar., C, Kaur., A, Arora., R, Shah., L, Nain, 2015. Improvement of antioxidant and defense properties of tomato (var. Pusa Rohini) by application of bioaugmented compost Saudi J Biol Sci, 22 (2015): $256-264$.

[46] Rady, M.M., W.M. Semida, K.A. Hemida, M.T. Abdelhamid, 2016. The effect of compost on growth and yield of Phaseolus vulgaris plants grown under saline soil . Int J Recycl Org Waste Agricult., 5(4): 311-321.

[47] Tautges, N.E., J. L. Chiartas, A.C.M. Gaudin, A.T. O’Green, I. Herrera and K.M. Scow, 2019. Deep soil inventories reveal that impacts of cover crops and compost on soil carbon sequestration differ in surface and subsurface soils. Global Change Biology 00:1-14.

[48] Iverson, S.L and R.M. Maier, 2009. Effects of compost on colonization of roots of plants grown in metalliferous mine tailings, as examined by fluorescence in situ hybridization. Applied and Environmental Microbiology, 75 (3): 842- 847.

[49] Diacono, M and F. Montemurro, 2010. Long-term effects of organic amendments on soil fertility. A review. Agronomy for sustainable development, Springer Verlag/EDP Sciences/INRA, 30 (2), ff10.1051/agro/2009040ff. ffhal-00886539f. 
[50] Nguyen, T.T., 2013. Compost effects on soil water content, plant growth under drought and nutrient leaching. Thesis for Doctor Philosophy Degree, Adelaide University, Australia

[51] Mayak, S., T, Tirosh and B.R. Glick, 2004. Plant growth promoting bacteria confer resistance in tomato plants to salt stress. Plant Physiol. Biochem., 42: 565-572.

[52] Boyer, J.S., P.J. Kramer, 1995. Water relations of plants and soils; Academic Press Inc.: Waltham, MA, USA, 1995; ISBN 978-0-12-425060-4.

[53] Lee, J and K.W. Mudge, 2013. Water deficit affects plant and soil water status, plant growth, and ginsenoside contents in American ginseng. Hortic Environ Biotechnol., 54:475-483.

[54] Jones, H.G., 2007. Monitoring plant and soil water status: established and novel methods revisited and their relevance to studies of drought tolerance, Journal of Experimental Botany, 58(2): 119-130.

[55] Nguyen, T.T., S, Fuentes., P, Marschner, 2012. Growth and water use efficiency of Capsicum annuum in a silt soil treated three years previously with a single compost application and repeatedly dried. International Journal of Vegetable Science, DOI:10.1080/19315260.2013.764508.

[56] Larchevèque, R., Desrochers., G, Larocque, 2011. Comparison of manure compost and mineral fertilizer for hybrid poplar plantation establishment on boreal heavy clay soils. Annals of Forest Science, Springer Verlag/EDP Sciences, 68 (4):849860.

[57] Adugna, G., 2016. A review on impact of compost on soil properties, water use and crop productivity. Agricultural Science and Research, 4(3): 93-104.

[58] Lugojan, C and S. Ciulca, 2011. Evaluation of relative water content in winter wheat. J. Hortic. Fores. Biotechnol., 15: $173-177$.

[59] Soltys-Kalina, D., J. Plich, D. Strzelczyk-Żyta, J. Śliwka, W. Marczewski, 2016. The effect of drought stress on the leaf relative water content and tuber yield of a half-sib family of 'Katahdin'-derived potato cultivars. Breed Sci., 66(2):328-331. doi: $10.1270 /$ jsbbs.66.328.

[60] Tanguilig, V.C., E.B. Yambao, J.C.O. Toole and S.K. De Datta, 1987. Water stress on leaf elongation, leaf water potential, transpiration and nutrient uptake of rice, maize and soybean. Plant Soil, 103: 155-168.

[61] Hu, Y., Z, Burucs., S.V. Tucher., U, Schmidhalter., 2007. Short-term effects of drought and salinity on mineral nutrient distribution along growing leaves of maize seedlings. Environmental and Experimental Botany, 60: 268-275.

[62] Tejada, M., A.M. Garcia-Martinez., and J, Parrado, 2009. Relationships between biological and chemical parameters on the composing of a municipal solid waste. Bioresource Technology, $100: 4062-4065$.

[63] Schroth, G., B. Vanlauwe, J.Lehmann, 2003. Soil organic matter. In tree, crop, and soil fertility : Concepts and research methods. Schroth G and Sinclair FL (Eds.) : 77 - 89. CABI Publishing, Cambridge.

[64] Gao, M., F. Liang, A.Yu, B. Li, L.Yang, 2010. Evaluation of stability and maturity during forced-aeration composting of chicken manure and sawdust at different $\mathrm{C} / \mathrm{N}$ ratios. Chemosphere, $78: 614-619$.

[65] Setiawati1, M.R., P. Suryatmana, Budiasih , N. Sondari, L. Nurlina, B.A. Kurnani and E. Harlia, 2018. Utilization Azolla pinnata as substitution of manure to improve organic rice yield and paddy soil health. IOP Conf. Series: Earth and Environmental Science, 215012006.

[66] Lazcano, C., J. Arnold, A.Tato, J.G. Zaller, J. Dominguez, 2009. Compost and vermicompost as nursery pot components: Effect on tomato plant growth and morphology. Spanish Journal of Agricultural Research, 7: 944 - 951.

\section{Author Biography}

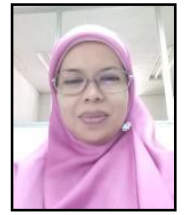

Dr. rer.nat Dwi Setyo Rini is a junior researcher at Research Center for Biology, Indonesian Institute of Sciences (LIPI), where she has worked since 2005. She graduated for her doctoral program from TUM-Germany to study the molecular response of drought-tolerant plants. After finishing her doctoral degree, she focuses her research on elucidating plant responses to drought stress. Plant characters based on morphoagronomical, physiological, and molecular parameters have been studied in order to figure out the complex mechanism of plant response under drought. 